\title{
Mathematical Model for Mers-CoV Disease Transmission with Medical Mask Usage and Vaccination
}

\author{
Muhammad Manaqib, Irma Fauziah, and Mujiyanti \\ Departement of Mathematics, Faculty of Sciences and Technology \\ UIN Syarif Hidayatullah Jakarta \\ Email: muhammad.manaqib@,uinjkt.ac.id
}

\begin{abstract}
This study developed a model of the spread of MERS-CoV disease using the SEIR model which was added by a health mask and vaccination factor as a preventive measure. The population is divided into six subpopulations namely susceptible subpopulations not using health masks and using health masks, exposed subpopulations, infected subpopulations not using health masks and using health masks, and recovering subpopulations. The results are obtained two equilibrium points, namely disease-free equilibrium points and endemic equilibrium points. Analysis of the stability of the disease-free equilibrium point using linearization around the equilibrium point. As a result, the asymptotic stable disease-free local equilibrium point if the base reproduction number is less than one. Numerical simulation models for MERS-CoV disease are carried out in line with the analysis of model behavior. Keywords: MERS-CoV, SEIR Model, Stability Equilibrium Point, Basic Reproduction Number.
\end{abstract}

\begin{abstract}
Abstrak
Penelitian ini mengembangkan model penyebaran penyakit MERS-CoV menggunakan model SEIR yang ditambahkan faktor masker kesehatan dan vaksinasi sebagai upaya pencegahan. Populasi dibagi menjadi enam subpopulasi yaitu subpopulasi rentan tidak menggunakan masker kesehatan dan menggunakan masker kesehatan, subpopulasi laten, subpopulasi terinfeksi tidak menggunakan masker kesehatan dan menggunakan masker kesehatan, serta subpopulasi sembuh. Hasilnya diperoleh dua titik ekuilibrium yaitu titik ekulibrium bebas penyakit dan endemik. Analisis kestabilan titik ekuilibrium bebas penyakit menggunakan linearisasi disekitar titik ekuilibrium. Hasilnya, titik ekuilibrium bebas penyakit stabil asimtotik lokal jika bilangan reproduksi dasar kurang dari satu. Simulasi numerik model untuk penyakit MERS-CoV yang dilakukan sejalan dengan analisis perilaku model.
\end{abstract}

Kata kunci: MERS-CoV, Model SEIR, Kestabilan Titik Ekuilibrium, Bilangan Reproduksi Dasar.

\section{INTRODUCTION}

Middle East Respiratory Syndrome-Corona Virus (MERS-CoV) is a respiratory syndrome caused by a corona virus that attacks the respiratory tract from mild to severe. Symptoms are cough, fever, and shortness of breath, which are acute and usually patients have a contemporary illness such as diabetes, chronic heart disease, hypertension, and chronic pulmonary disease, which can 
lead to death for His sufferer [1]. Based on information published by the World Health Organization (WHO) since the first time reported MERS-CoV disease in April 2012 to August 2019, as many as 2464 laboratories have confirmed MERS-CoV cases with the number of deaths of 850 individuals or $34.5 \%$ of 27 countries where as many as 2073 cases or $84 \%$ were reported from Saudi Arabia with total number of death is 772 individuals or $37.24 \%$ [2].

Research by Funk et al. [3] conducted in the Arab Peninsula countries mentions that MERS$\mathrm{CoV}$ virus was detected on camels and bats. However, this virus is not found in domestic animals such as horses, cows, buffalos, goats, chickens, and birds. The transmission of this virus spread is divided into three parts. The first spread of the virus between the camel and bat. The virus spreads through the direct contact of the infected animal or through the feces because the MERS-CoV virus can survive for 48 hours in a free environment. Secondly, the spread of viruses from animal to human is that it occurs if the human being consumes meat, milk, or camel urine that has been infected by the virus. Viruses can also be spread if humans make direct contact with the camel or bat infected with the MERS-CoV virus. Thirdly, the spread of humans occurs directly and indirectly. Direct through the phlegm of MERS-CoV sufferers when sneezing and indirectly through objects that have been contaminated with viruses [3].

The spread Model of MERS-CoV disease with third spread pattern has been discussed previously, as did by Aldila et al. [4] who develop the SIR model by dividing the susceptible compartment into two sub-compartments namely susceptible without medical mask and susceptible with medical mask, as well as the infected compartment is also divided into two subcompartments namely the compartments infected without medical mask and infected with medical mask, the model was developed to control MERS-CoV disease with health mask, a campaign on the importance of health mask usage and supportive care interventions. Syarifudin et al. [5] studies on administering Meningitis vaccine to prevent the spread of MERS-CoV disease against the population in two countries. Subsequently, Beay [6] studied the treatment influence of MERS-CoV spread.

In the mid of 2015 MERS-CoV outbreak had plagued South Korea, then Kim et al. [7] researched the characteristics of MERS-CoV's spread in South Korea by forming and analyzing MERS-CoV's mathematical deployment model by dividing individual compartments into six categories i.e. susceptible (S), exposed (E), and infected (I), infection but asymptotic class (A), hospitalized (H), and recovery class (R). Subsequently, in 2016 Benny Yong and Livia Owen [8] formed a model describes the population dynamics of the spread of MERS-CoV infectious disease due to the displacement of individuals between region Indonesia and Saudi Arabia.

Seeing the spread of MERS-CoV disease that is increasingly the plague and fatalities, this should be wary of the Indonesian government because of many Indonesians who travel to Saudi Arabia to carry out Hajj and Umrah. Based on data from the Ministry of Religious Affairs, 205.886 Indonesians departed for Saudi Arabia to perform the Hajj pilgrimage recorded in 2018 [5]. The number is still added to the Indonesian people who run Umrah with an average of 195 people per day. Considering the spread of the virus, the efforts to prevent the spread of viruses that the Indonesian government can do is by using medical masks and enhancing human immunity with the administration of vaccines [1]. However, until now there are still no available vaccines and special treatment for MERS-CoV patients although attempts to find vaccines are still in progress [9] [10]. Because the vaccine has not been found for this disease, the vaccine is given in the form 
of the Meningitis vaccine to increase the immune system to prevent disease. Vaccination is a preventive action, so the administration of the vaccine is done to reduce the chances of getting hit by the virus MERS-CoV [5]. The use of medical masks for MERS-CoV sufferers can prevent the transmission of the virus from sputum when the sufferer sneezes. For healthy humans is also very important to avoid exposure to viruses from MERS-CoV sufferers.

One approach to explaining the solution to the real-world problem is to model or formulate a real problem in the language of mathematics. Once the mathematical model is obtained it can be solved mathematically and can be applied again in real problems. In this study, a mathematical model of the spread of MERS in the disease was established with the Meningitis vaccine as well as the use of medical masks. This model assumes that individuals who are given a Meningitis vaccine become immune to diseases and individuals who wear medical masks cannot be infected or transmit MERS-CoV disease.

\section{MATHEMATICAL MODEL}

This section will be formed a mathematical model of MERS-CoV disease with the Meningitis vaccine as well as the use of medical masks. This Model divides the individual population divided into six compartments i.e. susceptible individuals without the use of health masks $S_{1}(t)$, susceptible individuals using health masks $S_{2}(t)$, latent individuals $E(t)$, infected individuals without using health masks $I_{2}(t)$, individuals Infected with individual health mask $I_{2}(t)$, individual recovered $R(t)$ and $S_{1}(t) \geq 0, S_{2}(t) \geq 0, E(t) \geq 0, I_{1}(t) \geq 0, I_{2}(t) \geq 0, R(t) \geq 0$. For simplification analogized $S_{1}(t)=S_{1}, S_{2}(t)=S_{2}, E(t)=E, I_{1}(t)=I_{1}, I_{2}(t)=I_{2}$, and $R(t)=R$. used latent class (exposed) due to the incubation period of MERS-CoV virus to cause the disease is 2 to 14 days [11] [12]. The assumed total population (N) is constant, with $\mathrm{N}=S_{1}+S_{2}+E+I_{1}+I_{2}+R$.

In the formation models, we use the assumptions: (1) the population is assumed to be closed, (2) the number of births and the death amount of each unit of time is assumed to equal to rate $\mu$, (3) the population is homogeneously mixed, meaning that each individual has the same opportunity to make contact with other individuals, (4) individuals who are born and not vaccinated will enter into the $S_{1}$ compartment at rate $(1-\rho) \mu$, (5) susceptible individuals will be given vaccinations with certain vaccination measures so that it can lead to individuals given vaccines immune to disease by rate $\rho$, (6) susceptible individuals with health masks cannot be infected by MERS-CoV virus with a rate of awareness of the use of masks $u_{1}$, (7) individuals on the compartment $S_{2}$ will be re-placed to $S_{1}$ if they stop using a health mask, so individuals are on infected compartment at rate $u_{2}$, (8) virus infections occur when contact with an infected individual in the infected compartment, either directly or indirectly at a rate $\beta$, (9) individuals infected with the virus experience a latent period of pace $\delta,(10)$ virus-infected individuals can recover from disease by rate $\sigma,(11)$ individuals who have recovered cannot return to being susceptible individuals, (12) the death from illness is ignored, natural death only occurs in each subpopulation at a rate $\mu_{2}$.

With a schematic of the spread of MERS-CoV disease, the health mask usage and vaccination in a population can be presented in the transfer diagram in Figure 1. 


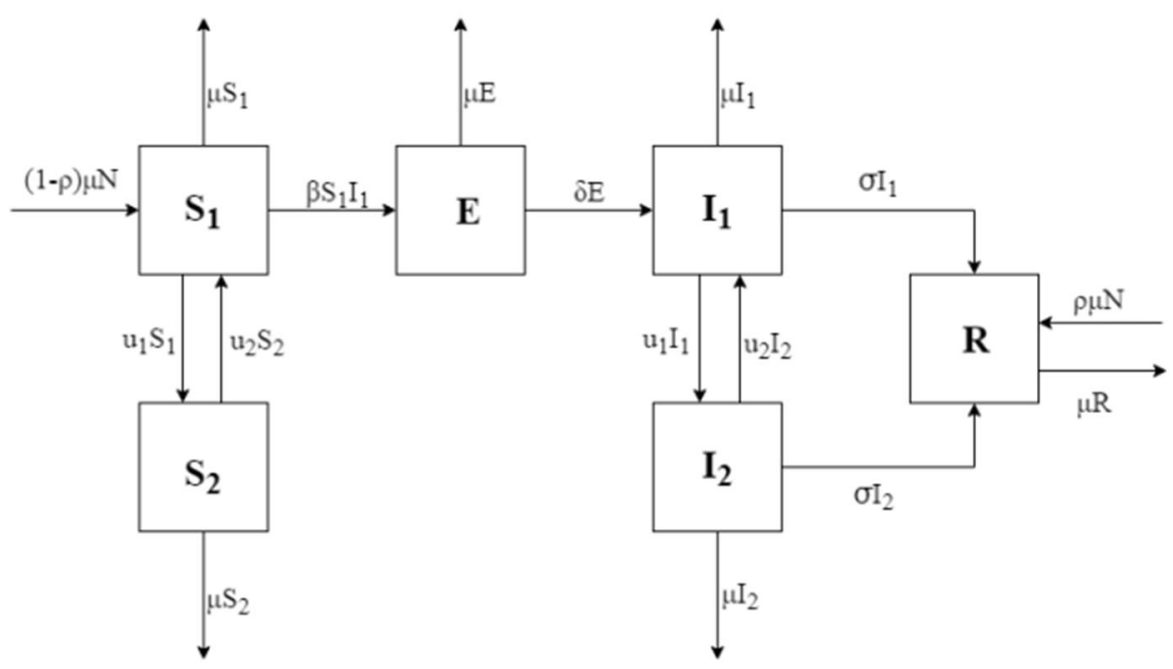

Figure 1. The diagram of transfer model of spread diseases MERS-CoV.

The mathematical model above transfer diagram can be expressed as follows:

$$
\begin{aligned}
& \frac{d S_{1}}{d t}=(1-\rho) \mu N+u_{2} S_{2}-\left(\mu+u_{1}\right) S_{1}-\beta S_{1} I_{1} \\
& \frac{d S_{2}}{d t}=u_{1} S_{1}-\left(\mu+u_{2}\right) S_{2} \\
& \frac{d E}{d t}=\beta S_{1} I_{1}-(\mu+\delta) E \\
& \frac{d I_{1}}{d t}=\delta E+u_{2} I_{2}-\left(\mu+u_{1}+\sigma\right) I_{1} \\
& \frac{d I_{2}}{d t}=u_{1} I_{1}-\left(\mu+u_{2}+\sigma\right) I_{2} \\
& \frac{d R}{d t}=\sigma I_{1}+\sigma I_{2}+\rho \mu N-\mu R .
\end{aligned}
$$

From the system (1) obtained $\frac{d N}{d t}=0$, so $N(t)=k$ to $\mathrm{k}$ the real number of positive, therefore proved $N(t)$ is constant.

The system (1) is formed in a non-dimensional model, to simplify the system (1). The proportion of the number of individual compartments can be expressed as follows:

$$
s_{1}=\frac{S_{1}}{N}, s_{2}=\frac{S_{2}}{N}, e=\frac{E}{N}, i_{1}=\frac{I_{1}}{N}, i_{2}=\frac{I_{2}}{N}, r=\frac{R}{N} .
$$

From equation (2), we obtain

$$
s_{1}+s_{2}+e+i_{1}+i_{2}+r=\frac{S_{1}}{N}+\frac{S_{2}}{N}+\frac{E}{N}+\frac{I_{1}}{N}+\frac{I_{2}}{N}+\frac{R}{N}=1 .
$$

So that the equation system (1) can be formed into non-dimensional models to: 


$$
\begin{aligned}
& \frac{d \dot{s}_{1}}{d t}=(1-\rho) \mu+u_{2} s_{2}-\left(\mu+u_{1}\right) s_{1}-\beta s_{1} i_{1} \\
& \frac{d \dot{s}_{2}}{d t}=u_{1} s_{1}-\left(\mu+u_{2}\right) s_{2} \\
& \frac{d \dot{e}}{d t}=\beta s_{1} i_{1}-(\mu+\delta) e \\
& \frac{d \dot{i}_{1}}{d t}=\delta e+u_{2} i_{2}-\left(\mu+u_{1}+\sigma\right) i_{1} \\
& \frac{d \dot{i}_{2}}{d t}=u_{1} i_{1}-\left(\mu+u_{2}+\sigma\right) i_{2} \\
& \frac{d \dot{r}}{d t}=\sigma i_{1}+\sigma i_{2}+\rho \mu-\mu r
\end{aligned}
$$

Furthermore, the system (3) variable $r$ does not appear in other equations. This suggests that the number of individuals in the $r$ compartment does not affect the rate of change in the number of individuals in the other compartment, then the equation $r$ for a while can be ignored from the system. So the system (3) can be written into:

$$
\begin{aligned}
& \frac{d \dot{s}_{1}}{d t}=(1-\rho) \mu+u_{2} s_{2}-\left(\mu+u_{1}\right) s_{1}-\beta s_{1} i_{1} \\
& \frac{d \dot{s}_{2}}{d t}=u_{1} s_{1}-\left(\mu+u_{2}\right) s_{2} \\
& \frac{d e}{d t}=\beta s_{1} i_{1}-(\mu+\delta) e \\
& \frac{d i_{1}}{d t}=\delta e+u_{2} i_{2}-\left(\mu+u_{1}+\sigma\right) i_{1} \\
& \frac{d i_{2}}{d t}=u_{1} i_{1}-\left(\mu+u_{2}+\sigma\right) i_{2}
\end{aligned}
$$

The system (4) is a nonlinear differential equation system that presents the spread of the MERS-CoV disease model with health mask usage and vaccinations.

\section{MODEL ANALYSIS}

The analysis model is carried out by the stability of the equilibrium point of the model. The equilibrium point is obtained by creating an equation on the system (4) equal to zero as follows:

$$
\begin{aligned}
(1-\rho) \mu+u_{2} s_{2}-\left(\mu+u_{1}\right) s_{1}-\beta s_{1} i_{1} & =0 \\
u_{1} s_{1}-\left(\mu+u_{2}\right) s_{2} & =0 \\
\beta s_{1} i_{1}-(\mu+\delta) e & =0 \\
\delta e+u_{2} i_{2}-\left(\mu+u_{1}+\sigma\right) i_{1} & =0 \\
u_{1} i_{1}-\left(\mu+u_{2}+\sigma\right) i_{2} & =0
\end{aligned}
$$


First, to find the equilibrium free disease that is the point of equilibrium when there is no infected in the population, so that $i_{1}=i_{2}=0$. Next to complete the equilibrium point (5) obtained free of disease system (4) as follows: [5]

$$
E_{1}\left(s_{1}, s_{2}, e, i_{1}, i_{2}\right)=\left(\frac{(1-\rho)\left(\mu+u_{2}\right)}{\mu+u_{1}+u_{2}}, \frac{u_{1}(1-\rho)}{\mu+u_{1}+u_{2}}, 0,0,0\right)
$$

Furthermore, it will be sought endemic equilibrium point that is the equilibrium point when the class is infected is not zero or when the disease spreads in the population. Endemic disease means that in the population there are always individuals who have the disease so that $I$ obtained at the endemic equilibrium point of the disease that is $i_{1}^{*}>0$ and $i_{2}^{*}>0$. Obtained of the endemic equilibrium point system (4) is $E_{2}=\left(s_{1}^{*}, s_{2}^{*}, e^{*}, i_{1}^{*}, i_{2}^{*}\right)$ with

$$
\begin{aligned}
s_{1}^{*} & =\frac{(\mu+\sigma)\left(\mu+u_{1}+u_{2}+\sigma\right)(\mu+\delta)}{\beta \delta\left(\mu+u_{2}+\sigma\right)} \\
s_{2}^{*} & =\frac{u_{1} s_{1}^{*}}{\left(\mu+u_{2}\right)} \\
e^{*} & =\frac{\beta s_{1}^{*} i_{1}^{*}}{(\mu+\delta)} \\
i_{1}^{*} & =\frac{\mu}{\beta}\left(\frac{\beta \delta n(1-\rho)\left(\mu+u_{2}\right)-d(\mu+\sigma)(d+\sigma) c}{(\mu+\sigma)(d+\sigma) c\left(\mu+u_{2}\right)}\right) \\
i_{2}^{*} & =\frac{u_{1} i_{i}^{*}}{\left(\mu+u_{2}+\sigma\right)}
\end{aligned}
$$

where $c=(\mu+\delta), d=\left(\mu+u_{1}+u_{2}\right), n=\left(\mu+u_{2}+\sigma\right)$.

Then, determine the basic reproduction number of $\left(R_{0}\right)$ the system (4) with the next-generation matrix method. The system Determination steps $\left(R_{0}\right)$ system (4), as [13] [14]:

1. Take the equations that describe the case of new infections and changes in the infection compartment of the system. Furthermore, this system is called an infected subsystem. On the System (4), the infected subsystem is $e, i_{1}$ and $i_{2}$.

2. Do linearization against infected subsystems at the disease-free equilibrium point. This linear system is represented by the Jacobi matrix, $\boldsymbol{J}$, as follows:

$$
\mathbf{J}_{\left(s_{1}, s_{2}, e, i_{1}, i_{2}\right)}=\left[\begin{array}{ccc}
-(\mu+\delta) & \frac{\beta(1-\rho)\left(\mu+u_{2}\right)}{\left(\mu+u_{1}+u_{2}\right)} & 0 \\
\delta & -\left(\mu+u_{1}+\sigma\right) & u_{2} \\
0 & u_{1} & -\left(\mu+u_{2}+\sigma\right)
\end{array}\right]
$$

3. The decomposition of the Jacobi matrix $(\mathbf{J})$ becomes $\mathbf{J}=\mathbf{F}-\mathbf{V}$, with $\mathbf{F}$ is the transmission matrix and $\mathbf{V}$ is the transmission matrix. 


$$
\mathbf{F}=\left[\begin{array}{ccc}
0 & \frac{\beta(1-\rho)\left(\mu+u_{2}\right)}{\left(\mu+u_{1}+u_{2}\right)} & 0 \\
0 & 0 & 0 \\
0 & 0 & 0
\end{array}\right], \quad \mathbf{V}=\left[\begin{array}{ccc}
(\mu+\delta) & 0 & 0 \\
-\delta & \left(\mu+u_{1}+\sigma\right) & -u_{2} \\
0 & -u_{1} & \left(\mu+u_{2}+\sigma\right)
\end{array}\right]
$$

4. From the equation (7) acquired matrix $\mathbf{V}$ inverse is

$$
\mathbf{V}^{-1}=\left[\begin{array}{ccc}
\frac{1}{\mu+\delta} & 0 & 0 \\
\frac{\delta\left(\mu+u_{2}+\sigma\right)}{(\mu+\delta) A} & \frac{\left(\mu+u_{2}+\sigma\right)}{A} & \frac{u_{2}}{A} \\
\frac{\delta u_{1}}{(\mu+\delta) A} & \frac{u_{1}}{A} & \frac{\left(\mu+u_{1}+\sigma\right)}{A}
\end{array}\right] .
$$

So that the matrix $\mathbf{F} \mathbf{V}^{-1}$ obtained is as follows:

$$
\mathbf{F V}^{-1}=\left[\begin{array}{ccc}
\frac{B \delta\left(\mu+u_{2}+\sigma\right)}{\left(u_{1}+u_{2}+\mu\right)(\mu+\delta) A} & \frac{B\left(\mu+u_{2}+\sigma\right)}{\left(u_{1}+u_{2}+\mu\right) A} & \frac{B u_{2}}{\left(u_{1}+u_{2}+\mu\right) A} \\
0 & 0 & 0 \\
0 & 0 & 0
\end{array}\right] .
$$

with $A=(\mu+\sigma)\left(\mu+u_{1}+u_{2}+\sigma\right)$ and $B=\beta(1-\rho)\left(\mu+u_{2}\right)$.

5. Find $R_{0}$ with $R_{0}=\rho\left(\mathbf{F V}^{-1}\right)$

By completing the equation $\operatorname{det}\left(\lambda \mathbf{I}-\mathbf{F V}^{-1}\right)=0$ or $\left(\lambda-\frac{\beta \delta(1-\rho)\left(\mu+u_{2}\right)\left(\mu+u_{2}+\sigma\right)}{\left(u_{1}+u_{2}+\mu\right)(\mu+\delta) A}\right) \lambda^{2}=0$,

obtained $\lambda_{1,2}=0$ and $\lambda_{3}=\frac{\beta \delta(1-\rho)\left(\mu+u_{2}\right)\left(\mu+u_{2}+\sigma\right)}{\left(u_{1}+u_{2}+\mu\right)(\mu+\delta) A}$.

As $R_{0}$ obtained from spectral radius or the greatest value of the eigenvalues, then obtained

$$
R_{0}=\frac{\beta \delta(1-\rho)\left(\mu+u_{2}\right)\left(\mu+u_{2}+\sigma\right)}{\left(u_{1}+u_{2}+\mu\right)(\mu+\delta) A}
$$

with $A=(\mu+\sigma)\left(\mu+u_{1}+u_{2}+\sigma\right)$.

\section{Teorema 1}

1) If $R_{0}<1$ then the system (4) has only one equilibrium point, i.e., the equilibrium point is free of the disease $E_{1}$.

2) If $R_{0}>1$ then the System (4) only has two equilibrium points, i.e., the free equilibrium point of this disease is $E_{1}$ and the equilibrium is endemic to $E_{2}$. 
Proof: To prove theorem 1 needs to be demonstrated if $R_{0}>1$ then the equilibrium point $\mathrm{E}_{2}$ exists. The existence of an equilibrium point is indicated by each of its positive elements as per the condition of forming this model. Note that $s_{1}^{*}$ and $s_{2}^{*}$ at the equivalence point of $E_{2}=\left(s_{1}^{*}, s_{2}^{*}, e^{*}, i_{1}^{*}, i_{2}^{*}\right)$ the equation (6) is clearly positive $e, i_{2}^{*}$ and positive if $i_{1}^{*}$ positive, so it needs to be demonstrated $i_{1}^{*}>0$. Substitution $c=(\mu+\delta) d=\left(\mu+u_{1}+u_{2}\right) n=\left(\mu+u_{2}+\sigma\right)$ to $n=\left(\mu+u_{2}+\sigma\right)$ be obtained:

$$
\begin{gathered}
i_{1}^{*}=\frac{\mu}{\beta}\left(\frac{\beta \delta\left(\mu+u_{2}+\sigma\right)(1-\rho)\left(\mu+u_{2}\right)-\left(\mu+u_{1}+u_{2}\right)(\mu+\sigma)\left(\mu+u_{1}+u_{2}+\sigma\right)(\mu+\delta)}{(\mu+\sigma)\left(\mu+u_{1}+u_{2}+\sigma\right)(\mu+\delta)\left(\mu+u_{2}\right)}\right) \\
R_{0}=\frac{\beta \delta(1-\rho)\left(\mu+u_{2}\right)\left(\mu+u_{2}+\sigma\right)}{\left(u_{1}+u_{2}+\mu\right)(\mu+\delta)(\mu+\sigma)\left(\mu+u_{1}+u_{2}+\sigma\right)}>1 \\
\Leftrightarrow \beta \delta\left(\mu+u_{2}+\sigma\right)(1-\rho)\left(\mu+u_{2}\right)>\left(\mu+u_{1}+u_{2}\right)(\mu+\sigma)\left(\mu+u_{1}+u_{2}+\sigma\right)(\mu+\delta)
\end{gathered}
$$

It's observed that equations 13 positive and based on (10) denominator (9) are also positive, resulting in a proven $i_{1}^{*}>0$.

\section{Theorem 2}

If $R_{0}<1$ then $E_{1}$ disease-free Equilibrium point, system (4) stable asymptotic local. Proof of the value of Eigen matrix Jacobi from the System (4) at the $E_{1}$ disease-free equilibrium point is obtained from the following dispute

$$
\Leftrightarrow\left|\begin{array}{ccccc}
\lambda+a & -u_{2} & 0 & \beta \frac{b(1-\rho)}{d} & 0 \\
-u_{1} & \lambda+b & 0 & 0 & 0 \\
0 & 0 & \lambda+c & -\beta \frac{b(1-\rho)}{d} & 0 \\
0 & 0 & -\delta & \lambda+m & -u_{2} \\
0 & 0 & 0 & -u_{1} & \lambda+n
\end{array}\right|=0
$$

where $\quad a=\mu+u_{1}, b=\mu+u_{2}, c=\mu+\delta, d=\mu+u_{1}+u_{2}, m=a+\sigma, n=b+\sigma, \quad$ so that obtained the characteristic equation for $J_{\left(E_{1}\right)}$ is

$$
\begin{array}{cc}
\Leftrightarrow \quad & (\lambda+a)\left[(\lambda+b)\left[(\lambda+c)(\lambda+m)(\lambda+n)-(\lambda+c)\left(u_{1} u_{2}\right)-\frac{\delta \beta b(1-\rho)}{d}(\lambda+n)\right]\right] \\
& +u_{2}\left[\left(-u_{1}\right)\left[(\lambda+c)(\lambda+m)(\lambda+n)-(\lambda+c)\left(u_{1} u_{2}\right)-\frac{\delta \beta b(1-\rho)}{d}(\lambda+n)\right]\right]=0
\end{array}
$$

Obtained $\lambda_{1}=-\mu$ and $\lambda_{2}=-\mu-u_{1}-u_{2}$, because $\mu, u_{1}$, and $u_{2}$ positive value, then the real part of both Eigenvalues are negative. The other Eigenvalues are the polynomial roots as follow: 


$$
(\lambda+c)(\lambda+m)(\lambda+n)-(\lambda+c)\left(u_{1} u_{2}\right)-\frac{\delta \beta b(1-\rho)}{d}(\lambda+n)=0
$$

The equation (11) can be written as:

$$
\lambda^{3}+\lambda^{2}(m+n+c)+\lambda((\mu+\sigma)(d+\sigma)+c(m+n)-Q)+c(\mu+\sigma)(d+\sigma)-Q n=0
$$

obtained $a_{0}=1, \quad a_{1}=m+n+c, \quad a_{2}=((\mu+\sigma)(d+\sigma)+c(m+n)-Q) \quad$ and $a_{3}=c(\mu+\sigma)(d+\sigma)-Q n$, with $Q=\frac{\delta \beta b(1-\rho)}{d}$.

Based on the Routh-Hurwitz criteria, all Eigenvalues (12) will be of negative value if and only if $a_{0}, a_{1}, a_{2}, a_{3}$ and $\Delta_{1}, \Delta_{2}, \Delta_{3}$ of the Matrix Routh Hurwitz is positively positive. Because $a_{0}=1$ positive is worth it will be demonstrated $a_{1}>0, a_{2}>0$ and $a_{3}>0$. Note

$$
a_{1}=(m+c+n)=\mu+u_{1}+\sigma+\mu+\delta+\mu+u_{2}+\sigma=3 \mu+2 \sigma+u_{1}+u_{2}+\delta
$$

discovered $\mu \geq 0, \sigma \geq 0, u_{1} \geq 0$ and $u_{2} \geq 0$ then clear $a_{1}>0$. Next $a_{2}$ and $a_{3}$ must be positive, it must be

$$
(\mu+\sigma)\left(\mu+u_{1}+u_{2}+\sigma\right)-\frac{\beta \delta\left(\mu+u_{2}\right)(1-\rho)}{\left(\mu+u_{1}+u_{2}\right)}+c(m+n)>0
$$

and

$$
(\mu+\delta)(\mu+\sigma)\left(\mu+u_{1}+u_{2}+\sigma\right)-\frac{\beta \delta(1-\rho)\left(\mu+u_{2}\right)}{\left(\mu+u_{1}+u_{2}\right)}\left(\mu+u_{2}+\sigma\right)>0
$$

Based on the equation (8) for $R_{0}<1$ obtained

$$
(\mu+\sigma)\left(\mu+u_{1}+u_{2}+\sigma\right)-\frac{\beta \delta(1-\rho)\left(\mu+u_{2}\right)}{\left(\mu+u_{1}+u_{2}\right)} \frac{\left(\mu+u_{2}+\sigma\right)}{(\mu+\delta)}>0
$$

By using the same formula obtained,

$$
(\mu+\delta)(\mu+\sigma)\left(\mu+u_{1}+u_{2}+\sigma\right)-\frac{\beta \delta(1-\rho)\left(\mu+u_{2}\right)}{\left(\mu+u_{1}+u_{2}\right)}\left(\mu+u_{2}+\sigma\right)>0
$$

Based on the equation (16) and (17), proven that equation (14) and (15) positive so that $a_{2}>0$ and $a_{3}>0$.

Defined matrix Routh Hurwitz as follows:

$$
H=\left[\begin{array}{lll}
a_{1} & a_{0} & 0 \\
a_{3} & a_{2} & a_{1} \\
a_{5} & a_{4} & a_{3}
\end{array}\right]=\left[\begin{array}{ccc}
m+c+n & 1 & 0 \\
c(\mu+\sigma)(d+\sigma)-Q n & (\mu+\sigma)(d+\sigma)+c(m+n)-Q & m+c+n \\
0 & 0 & c(\mu+\sigma)(d+\sigma)-Q n
\end{array}\right]
$$

Based matrix $H$, determine obtained matrix Routh Hurwitz as follow: 


$$
\Delta_{1}=\left|a_{1}\right|, \Delta_{2}=\left|\begin{array}{ll}
a_{1} & a_{0} \\
a_{3} & a_{2}
\end{array}\right| \text { and } \Delta_{3}=\left|\begin{array}{ccc}
a_{1} & a_{0} & 0 \\
a_{3} & a_{2} & a_{1} \\
0 & 0 & a_{3}
\end{array}\right|=a_{3}\left(a_{1} a_{2}-a_{3}\right)=a_{3}\left(\Delta_{2}\right)
$$

Based on the equation (13) it is clear that $a_{1}>0$ so that $\Delta_{1}>0$. Then $\Delta_{2}=a_{1} a_{2}-a_{3}>0$ so, it must

$$
\begin{gathered}
(m+n+c)[(\mu+\sigma)(d+\sigma)+c(m+n)-Q]-[c(\mu+\sigma)(d+\sigma)-Q n]>0 \\
\Leftrightarrow(m+n)[(\mu+\sigma)(d+\sigma)+(m+n+c) c]>(m+c) Q .
\end{gathered}
$$

Note if $R_{0}<1$

$$
\begin{array}{ll}
\Leftrightarrow & \frac{\beta \delta(1-\rho)\left(\mu+u_{2}\right)\left(\mu+u_{2}+\sigma\right)}{(\mu+\sigma)(\mu+\delta)\left(\mu+u_{1}+u_{2}\right)\left(\mu+u_{1}+u_{2}+\sigma\right)}<1 \\
\Leftrightarrow & Q \frac{n}{c(\mu+\sigma)(d+\sigma)}<1 \\
\Leftrightarrow & c(\mu+\sigma)(d+\sigma)>Q n \\
\Leftrightarrow \quad & (m+c) c(\mu+\sigma)(d+\sigma)>Q n(m+c) \\
\Leftrightarrow \quad & \frac{(m+c) c(\mu+\sigma)(d+\sigma)}{n}>Q(m+c)
\end{array}
$$

Based on the equation (19), then equation Error! Reference source not found. proven, so $\Delta_{2}>0$. Next to show that $\Delta_{3}>0$, because of $\Delta_{3}=a_{3}\left(\Delta_{2}\right), a_{3}>0$ and $\Delta_{2}>0$, so proven that $\Delta_{3}>0$. Determinant of the Routh Hurwitz matrix $\Delta_{1}, \Delta_{2}$ and $\Delta_{3}$ positive value if $R_{0}<1$. Thus the equation (12) has roots whose parts are negative. So it can be concluded that the disease-free equilibrium $E_{1}$ point is a local asymptotic stable.

\section{MODEL SIMULATION}

The simulation is performed using the Maple 18 program and by providing values for each parameter. This simulation is provided to provide a geometric picture related to the results that have been analyzed. Some of the parameter values used are taken from some previous studies regarding MERS-CoV disease (Table 1). Based on table 1, the disease will not spread, in other words for a certain period of time the population will be free from illness. Obtained by the disease-free equilibrium point is the $E_{1}\left(s_{1}, s_{2}, e, i_{1}, i_{2}\right)=(0.069532,0.130468,0,0,0)$.

Table 1. The parameter and unit are used in the simulation

\begin{tabular}{|c|c|c||c|c|c|}
\hline Parameter & Value & Unit & Parameter & Value & Unit \\
\hline \hline$\mu$ & 0.07305936073 & $\frac{1}{\text { day }}$ & $\beta$ & 0.1 & $\frac{1}{\text { individu } \times \text { day }}$ \\
\hline$\rho$ & 0.8 & & $\delta$ & 0.07142857143 & $\frac{\text { individu }}{\text { day }}$ \\
\hline$u_{1}$ & 0.7 & $\frac{1}{\text { day }}$ & $\sigma$ & 0.03333333333 & $\frac{\text { individu }}{\text { day }}$ \\
\hline$u_{2}$ & 0.3 & $\frac{1}{\text { day }}$ & $N$ & 2000 & individu \\
\hline
\end{tabular}




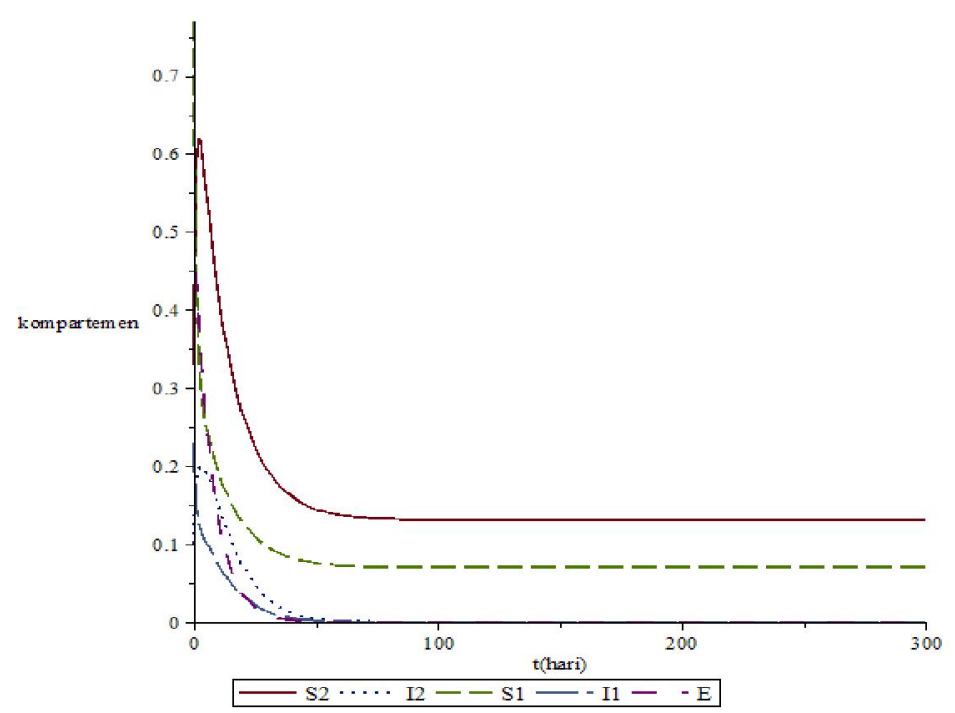

Figure 2. Simulation System (4) to a disease-free equilibrium point.

Based on figure 2 the vulnerable individual population does not use a health mask initially decreased, until on days 50 a vulnerable individual population does not use a health mask to reach a point and stabilize at that point. The individual population is susceptible to using decreased health masks until days 50 reaches a point of 0.130468 and is stable at that point. The infected individual population does not use a declining health mask until on day 40 it reaches a point 0 and stabilizes at that point. The population of individuals infected with health masks and latent individual decreases, until day 30 reaches the point 0 and stabilizes at that point. So in such simulations can be deduced the disease will disappear from the population after days 50 if $R_{0}<1$.

Next, we will simulate the system for $R_{0}>1$. If the parameter value $\beta$ is enlarged $45 \times 10^{-1}$ from the previous value to be $\beta=0.9$, the value of the $\delta$ parameter is enlarged $28 \times 10^{-1}$ to be $\delta=0.2$, and the value of the parameter $u_{1}, u_{2}$ and $\rho$ to be $u_{1}=0.1, u_{2}=0.9$ and $\rho=0.1$, then obtained $\mathrm{R}_{0}=4.599598$. Because $\mathrm{R}_{0}>1$, then the disease will spread in other words will occur epidemic. The acquired equilibrium point of the endemic system (4) that is $E_{2}\left(s_{1}^{*}, s_{2}^{*}, e, i_{1}^{*}, i_{2}^{*}\right)=(0.177434,0.018235$, 0.322234, 0.032019).

Based on Figure 3, the vulnerable individual population does not use health masks down to day 10, then up until day 50 to point 0.177434 and steady at that point. The individual population is susceptible to using health masks declining to day 10 and up to day 40 to the point 0.018235 and stable at that point. The latent individual population declined to the 30 th day to 0.188450 and stabilized at that point. The infected individual population does not use the health masks up until day 10 and down to day 50 to the point 0.322234 and stable at that point. The individual population infected with health masks decreased to the 20 th day towards the 0.032019 points and stabilized at that point. So in such simulations can be concluded in the end the disease will remain in the population if $R_{0}>1$. 


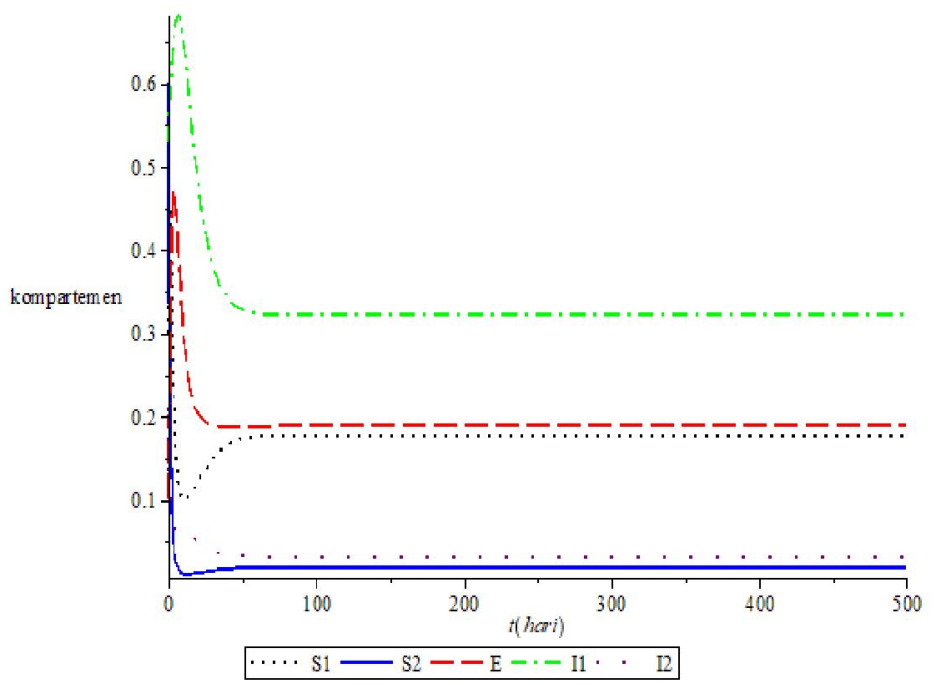

Figure 3. Simulation System (15) endemic equilibrium point.

Based on the theorem 2 and numerical simulation results, it was concluded that the disease would disappear from the population if the value $R_{0}<1$. So that, the recommendation of this research to prevent the disease MERS-CoV as follows:

1. Reduce the contact of vulnerable individuals with infected individuals $(\beta)$. For example, when flu is not to be outdoors for a while to prevent transmission to others and avoid using the same eating and drinking utensils with MERS-CoV sufferers.

2. Reduce the rate of release of health masks $\left(u_{2}\right)$ and increase the rate of use of health masks $\left(u_{1}\right)$ in susceptible and infected individuals.

3. Increase the proportion of vaccinated individuals $(\rho)$ in a region that becomes a MERS-CoV outbreak.

\section{CONCLUSIONS}

Based on the discussion that has been discussed earlier, the conclusion that the model form of the spread of the disease MERS-CoV with the use of health masks and vaccination is a differential nonlinear equivalent of one order. By analyzing the differential equation system in the nondimensional model obtained two equilibrium points, namely the disease-free equilibrium point and the endemic equilibrium point. The disease-free equivalence point is linearized by using the Jacobi matrix to stabilize asymptotically if $R_{0}<1$. To find out whether it is endemic or not in a region can be seen from the basic reproduction number $\left(R_{0}\right)$. The influential parameters in the $R_{0}$ of the individual's infected contact rate are vulnerable to the individuals $(\beta)$, latent individual rates into infected individuals $(\delta)$, the proportion of unvaccinated individuals $(1-\rho)$, natural rate of birth and death $(\mu)$, the usage rate of health masks $\left(u_{1}\right)$, health mask release rate $\left(u_{2}\right)$, and the level of individual healing of the disease $(\sigma)$. The simulated models were performed using the Maple 18 application, with parameter values drawn from several journals related to the spread of MERS-CoV disease and results showed that if the basic reproductive number is less than one then the disease will not spread, in other words for a certain period of time the population will be free from the disease. However, if the value of the parameter, $\beta, \delta, u_{2}$ is raised and the value of the parameter $\rho$ and lowered, the number of basic 
reproduction becomes more than one, then the disease will be spread, in other words, there will be an epidemic so that the infected and transmitted individuals will remain in the population.

\section{REFERENCES}

[1] Slamet and et al., Pedoman Umum Kesiapsiagaan Menghadapi Middle East Respiratory Syndrom-Corona Virus (MERS-Cov), Jakarta, 2013.

[2] G. Dudas, L. Carvalho and A. Rambaut, "MERS-CoV spillover at the camel-human interface," eLife, vol. 7, no. e31257, pp. 1-23, 2018.

[3] A. Funk, F. Goutard, E. Miguel, V. Chevalier, B. Faye and et al., "Mers-coV at the AnimalHuman Interface: Inputs on Exposure Pathways from an Expert-Opinion elicitation," Front. Vet. Sci., vol. 3, no. October, pp. 1-12, 2016.

[4] D. Aldila, H. Padma, K. Khotimah, B. Desjwiand and H. Tasman, "Analyzing The Mers Disease Control Strategy Through An Optimal Control Problem," Int.J. Appl. Math. Comput. Sci., vol. 28, no. 1, pp. 169-184, 2018.

[5] M. Syarifudin, D. Lestari and H. 'Arifah, "Stability Analysis of Epidemic Model Middle East Respiratory Syndrome-Corona Virus between Indonesia (INA) and Saudi Arabia (KSA)," in 4th ICRIEMS ProceedingsPublished byThe Faculty Of Mathematics And Natural Sciences, Yogyakarta, 2017.

[6] L. Beay, "Model Penyebaran Middle East Respiratory Syndrome (MERS) dengan Pengaruh Pengobatan," in Seminar Nasional Matematika dan Aplikasinya, Surabaya, 2017.

[7] Y. Kim, S. Lee, C. Chu and S. Choe, "The Characteristics of Middle Eastern Respiratory Syndrome Coronavirus Transmission Dynamics in South Korea," Osong Public Heal. Res. Perspect, vol. 7, no. 1, pp. 49-55, 2016.

[8] B. Yong and L. Owen, "Dynamical transmission model of MERS-CoV in two areas," AIP Conf. Proceeding, vol. 1716, 2016.

[9] A. Omrani, M. Matin, Q. Haddad, Z. Al-Nakhli, Z. Memish and A. Albarrak, "A family cluster of middle east respiratory syndrome coronavirus infections related to a likely unrecognized asymptomatic or mild case," Int. J. Infect. Dis., vol. 17, no. 9, pp. e668-e672, 2013.

[10] R. Kartika, M. Kwary, H. Bt Mohamad, M. Shazwan b. Sazali, N. Ayuni bt. M. Nasir and M. Afiq b. Che Rani, "Pengelolaan dan Pencegahan Middle East Respiratory Syndrome (MERS)," vol. 44, no. 4, pp. 2015-2018, 2017.," CDK-251, vol. 44, no. 4, pp. 244-247, 2017.

[11] J. Lee, "Better understanding on MERS Corona virus outbreak in Korea," J. Korean Med. Sci., vol. 30, no. 7, pp. 835-836, 2015.

[12] L. Rochmatika, S. Winarko and L. Hanafi, Penyelesaian Numerik dan Analisa Kestabilan pada Model Epidemik SEIR dengan Memperhatikan Adanya Penularan pada Periode Laten, Surabaya: Institut Teknologi Sepuluh Nopember, 2013.

[13] P. Van Den Driessche and J. Watmough, "Reproduction Numbers and Sub-threshold Endemic Equilibria for Compartmental Models of Disease Transmission," Math. Biosci., vol. 180, pp. 2948, 2002.

[14] K. Blyuss and Y. Kyrychko, "On a basic model of a two-disease epidemic," Appl. Math. Comput., vol. 160, no. 1, pp. 177-187, 2005. 